\title{
ANALYSIS OF ENERGY CONSUMPTION IN THE BUILDING AS THE BASIS FOR DEVELOPMENT OF THE MODULAR MODEL Predictive Control System
}

\author{
Boris Crnokić, Gordan Lješić, Željko Stojkić \& Marijana Bandić Glavaš \\ University of Mostar, Faculty of Mechanical Engineering, Computing and Electrical engineering, \\ Matice hrvatske bb, 88000, Mostar, BiH
}
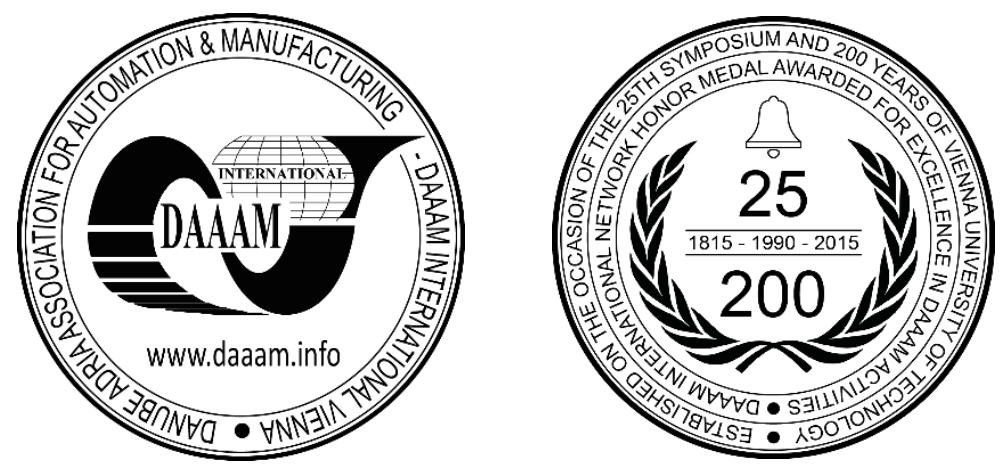

This Publication has to be referred as: Crnokic, B[oris]; Ljesic, G[ordan]; Stojkic, Z[eljko] \& Bandic Glavas, M[arijana] (2017). Analysis of Energy Consumption in the Building as the Basis for Development of the Modular Model Predictive Control System, Proceedings of the 28th DAAAM International Symposium, pp.0299-0308, B. Katalinic (Ed.), Published by DAAAM International, ISBN 978-3-902734-11-2, ISSN 1726-9679, Vienna, Austria DOI: $10.2507 / 28$ th.daaam.proceedings.041

\begin{abstract}
This paper gives a comprehensive report about development and validation of the dynamic model of an exemplary building, and comparison of energy consumption from the dynamic model with real energy consumption, as the basis for development of the modular Model Predictive Control (MPC) system. The model is created in IDA ICE professional building modelling software and its performance verified against energy consumption data from energy bills. Analysis and comparison of energy consumption will serve to equip the building with sensors and data acquisition equipment so as to include the whole building into one common Building Energy Management System (BEMS). One of the key parts for development of BEMS is dynamic model of the building, which is derived in this paper.
\end{abstract}

Keywords: Dynamic Building Model; Construction Data; Simulation Scenarios; Heating/Cooling Building Demand; Zone Temperature Dynamics; Building Data

\section{Introduction}

Energy efficiency is a very important aspect of the development of modern society. Due to the non-optimal design of buildings, imperfect heating and cooling systems or insufficiently efficient energy management systems, energy consumption in practice is higher than the building itself demands. Approximately $40 \%$ of world energy consumption is caused by the operation of various systems in buildings, which includes heating, cooling and air conditioning systems. [1] Conventional energy management systems (EMS) did not give the desired results in terms of energy savings. Model predictive control (MPC) has been recognized as one of the essential solutions to achieve considerable energy savings in buildings. [2] In order to address the problem of energy efficiency, more and more scientific and professional projects are 
being launched all over the world, in the EU, including separate regions such as the Danube region. One of those projects is also "Smart Building - Smart Grid - Smart City (3Smart)" project. Project is co-funded by the European Union through Interreg Danube Transnational Programme, and partners from the following countries are involved: Croatia, Slovenia, Austria, Hungary, Bosnia and Herzegovina and Serbia.

Current tendencies in the Danube Region to integrate energy-efficiency measures and renewable energy are not followed by their adequate interactions to enable optimal operation of the building as a whole. Distribution system operators are reluctant in allowing renewable energy in the grid as it engages investments into the grid and increases costs for its correct and secure operation. The main objective of the 3Smart (Fig 1.) project is to provide a technological and legislative setup for cross-spanning energy management of buildings, grids and major city infrastructures in the Danube Region. It will provide optimal economical value to energy-efficiency and renewable energy investment in the building and at the same time it will result in optimized costs on the grid side whereas grid and buildings will also interact through exchanging energy and prices data. This is expected to motivate installation of distributed storages in both buildings and grids for improving energy security in the Danube Region. [3]

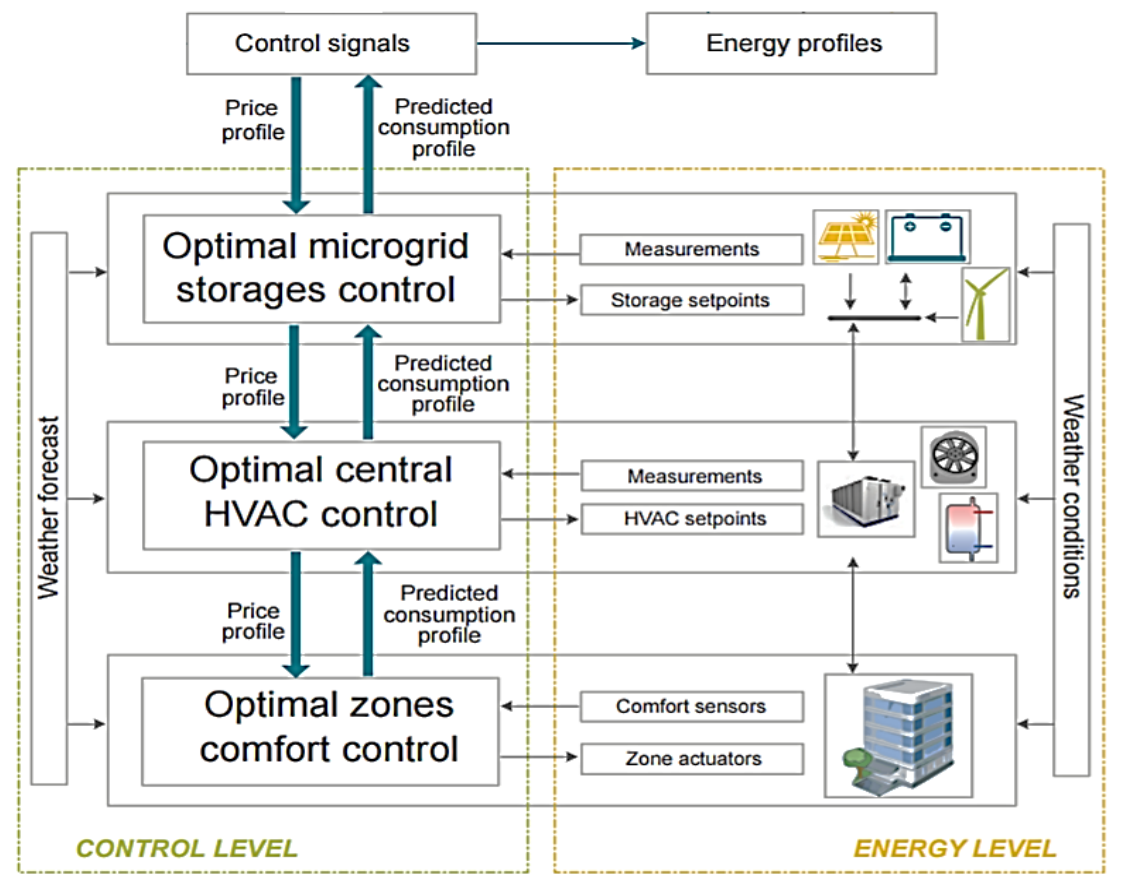

Fig. 1. The conceptual layout of 3Smart platform [3]

This paper presents one part of the project 3Smart, the thermodynamic model of the EPHZHB business building in Tomislavgrad (Bosnia and Herzegovina) which was used as one of the pilot buildings. The model is created in IDA ICE professional building modelling software and its performance verified against energy consumption data from energy bills. Building is consisted of one floor + ground floor and roof. The building is equipped with an advanced central control unit for heating/cooling, which enables the data acquisition from the building zone side to a central database. Based on these, the control commands for individual fan coils will be computed and transferred back through the existing communication network. This will result in a fully controllable building and in such way enable the zone-level smart predictive control for the entire building.

\section{Building architecture}

The building that is being considered in this paper is a pilot building of a project partner EPHZHB (JP Elektroprivreda Hrvatske Zajednice Herceg Bosne). Construction of the building in Tomislavgrad (Fig. 2) was finished in 2013. It has a useful area of $973,85 \mathrm{~m}^{2}$ and is located in the industrial zone of "Vučilov brig". The building has a quadratic shape with ground floor dimensions 23,45 x 23,45 [m] which enables a rational arrangement of office space at the circumference of the building and the central position of the entrance hall and the meeting room. All offices have same illumination, but because of simple construction quick and easy modifications are possible if necessary. Illumination is the same in all working areas and comes laterally, and the corridors are illuminated through glazed door walls. Meeting rooms are illuminated and ventilated indirectly across the hallway and lobby, and these two problems are solved through special treatment in installation projects. In the central area are also facilities that do not require lighting (sanitary block, kitchen, elevator) so all the useful space on the facade is used for office lighting. In the entrance hall are vertical communications, staircase and elevator. [4] 


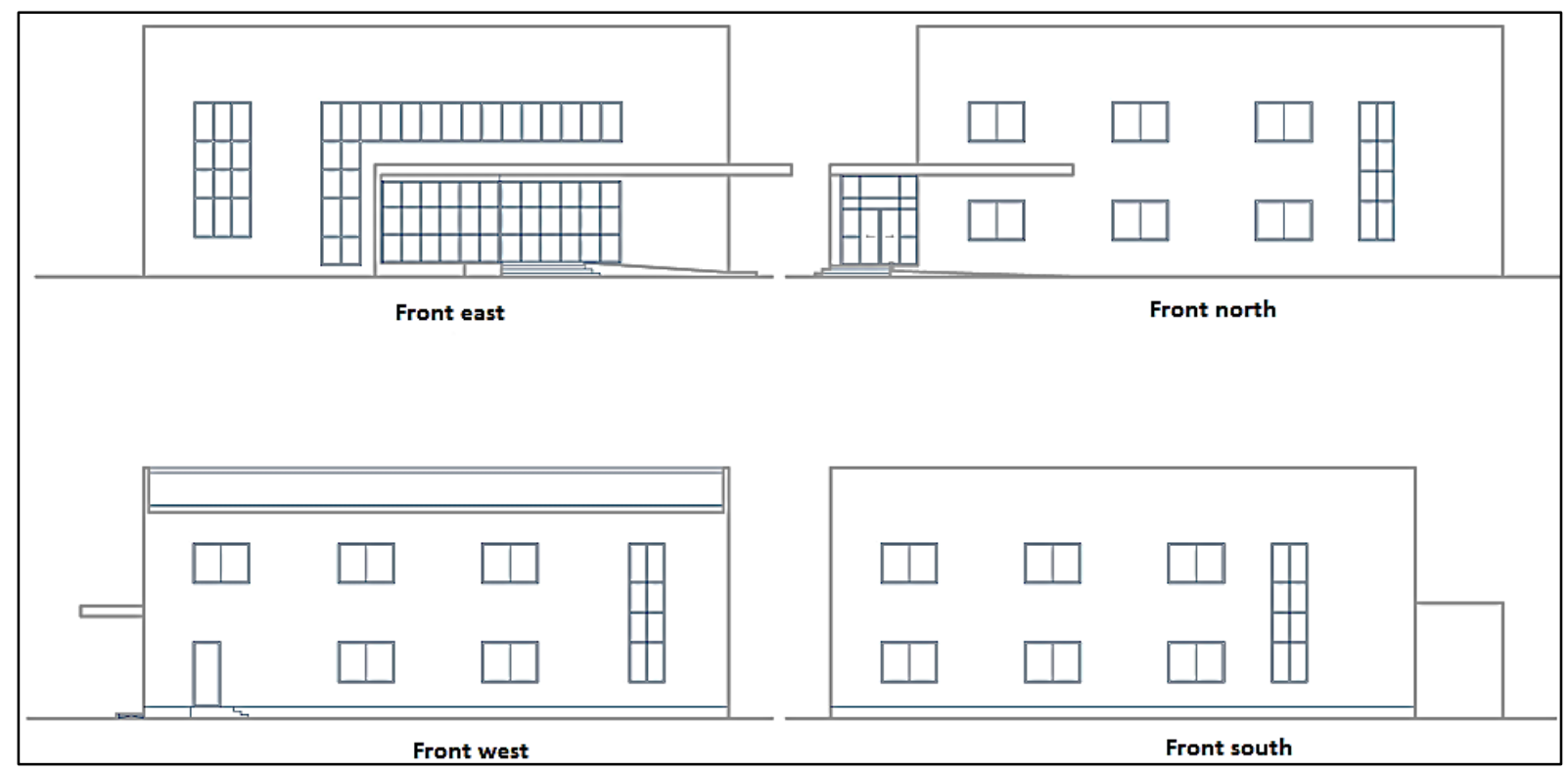

Fig. 2. All sides of the considered building [4]

\section{Building construction and materials}

The technical-constructive solution consists of a proper raster of supporting walls with reinforced concrete horizontal and vertical cerclages, and if necessary with poles and beams. The structure between two floors is made of reinforced concrete slab (MB 30) with a thickness of $20 \mathrm{~cm}$. The foundations were made of reinforced concrete slabs (MB 30) with a thickness of $60 \mathrm{~cm}$. The walls are made of bricks with a thickness of $25 \mathrm{~cm}$ with thermal insulating facade system with a thickness of $15 \mathrm{~cm}$. The roof structure consists of a wooden substructure on which a high quality panel is mounted. Thermal insulation is also mounted on reinforced concrete slab under the roof. External load-bearing walls are built with porotherm bricks $(25 \mathrm{~cm})$. On the inside of the wall is a layer of internal plaster $(3 \mathrm{~cm})$. Thermal insulation facade $(15$ $\mathrm{cm})$ consists of: facade styrofoam (EPS), construction adhesive, polypropylene mesh and mineral facade plaster. All internal bearing walls are made of gypsum board panels with a thickness of $22 \mathrm{~mm}$ with aluminium substructure, $10 \mathrm{~cm}$ of stone wool insulation and perforated acoustic panels $(12 \mathrm{~mm})$. The wall height is about $3.60 \mathrm{~m}$ and the fire resistance class is 90 . Total surface area of the internal bearing walls is 781,08 $\mathrm{m} 2$. [3] Detailed thermal properties of construction materials used in the building are given in Table 1.

\begin{tabular}{|c|c|c|c|c|c|c|}
\hline \multicolumn{2}{|c|}{ Building element } & $\begin{array}{c}\text { Layers } \\
\text { (inside-outside) } \\
\text { (top-bottom) }\end{array}$ & $\begin{array}{c}\text { Thic- } \\
\text { kness } \\
m \\
\end{array}$ & $\begin{array}{c}\text { Thermal } \\
\text { conductivity } \\
W / m K\end{array}$ & $\begin{array}{c}\text { Density } \\
\mathrm{kg} / \mathrm{m}^{3}\end{array}$ & $\begin{array}{c}\text { Specific } \\
\text { heat } \\
\mathrm{J} / \mathrm{kgK} \\
\end{array}$ \\
\hline \multirow{7}{*}{\multicolumn{2}{|c|}{ External walls }} & Render & 0,020 & 0,800 & 1800 & 790 \\
\hline & & Porotherm bricks & 0,250 & 0,141 & 750 & 1000 \\
\hline & & Construction adhesive & 0,001 & - & - & - \\
\hline & & Facade Styrofoam (EPS) & 0.100 & 0.035 & 29 & 1213 \\
\hline & & Construction adhesive & 0,001 & - & - & - \\
\hline & & Conctuption adbecing & 0001 & 0,100 & & $1 / 00$ \\
\hline & & $\begin{array}{l}\text { Construction adnesive } \\
\text { Mineral facade plaster }\end{array}$ & 0,020 & 1.400 & 880 & 2300 \\
\hline \multirow{13}{*}{$\begin{array}{l}\text { Internal } \\
\text { walls }\end{array}$} & \multirow{6}{*}{ Default walls } & Gypsum board & 0,022 & 0,160 & 950 & 840 \\
\hline & & Perforated acoustic panel & 0,012 & 0,370 & 117 & - \\
\hline & & Stone wool & 0,100 & 0.035 & 30 & 1000 \\
\hline & & Aluminium substructure & - & - & & 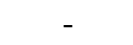 \\
\hline & & Perforated acoustic panel & 0,012 & 0,370 & 117 & - \\
\hline & & Gypsum board & 0,022 & 0,160 & 950 & 840 \\
\hline & \multirow{7}{*}{$\begin{array}{l}\text { Sanitary blocks } \\
\text { walls }\end{array}$} & Ceramic tiles & 0,008 & 1,200 & 2000 & 1000 \\
\hline & & Gypsum board & 0,022 & 0,160 & 950 & 840 \\
\hline & & Perforated acoustic panel & 0,012 & 0,370 & 117 & - \\
\hline & & Stone wool & 0,100 & 0,035 & 30 & 1000 \\
\hline & & Aluminium substructure & - & - & - & - \\
\hline & & Perforated acoustic panel & 0,012 & 0,370 & 117 & - \\
\hline & & Gypsum board & 0,022 & 0,160 & 950 & 840 \\
\hline
\end{tabular}




\begin{tabular}{|c|c|c|c|c|c|c|}
\hline & & Ceramic tiles & 0,008 & 1,200 & 2000 & 1000 \\
\hline \multirow[t]{2}{*}{ Floors } & Ground floor & $\begin{array}{l}\text { Floor coating: } \\
\text { polyamide carpet, } \\
\text { ceramic tiles, } \\
\text { decorative stone } \\
\text { Flooring screed MB } 30 \\
\text { Separating layer } \\
\text { Thermal layer-stone wool } \\
\text { Reinforced concrete slab MB } 30 \\
\text { Synthetic waterproof foil } \\
\text { Tampon-gravel } \\
\text { Tampon-stone }\end{array}$ & $\begin{array}{l}0,008 \\
0,010 \\
0,025 \\
0,060 \\
0,001 \\
0,050 \\
0,600 \\
0,002 \\
0,200 \\
0,200\end{array}$ & $\begin{array}{c}0,250 \\
1,200 \\
1,700 \\
0,412 \\
- \\
0,035 \\
2,600 \\
0,190 \\
1.441 \\
1,700\end{array}$ & $\begin{array}{c}1100 \\
2000 \\
2700 \\
1200 \\
- \\
30 \\
2500 \\
87 \\
1674 \\
2700\end{array}$ & $\begin{array}{c}1700 \\
1000 \\
920 \\
840 \\
- \\
1000 \\
1000 \\
840 \\
881 \\
920 \\
\end{array}$ \\
\hline & First floor & $\begin{array}{l}\text { Floor coating: } \\
\text { polyamide carpet, } \\
\text { ceramic tiles, } \\
\text { decorative stone } \\
\text { Flooring screed MB } 30 \\
\text { Separating layer } \\
\text { Thermal layer-stone wool } \\
\text { Reinforced concrete slab MB } 30\end{array}$ & $\begin{array}{l}0,008 \\
0,010 \\
0,025 \\
0,060 \\
0,001 \\
0,050 \\
0,200 \\
\end{array}$ & $\begin{array}{l}0,250 \\
1,200 \\
1,700 \\
0,412 \\
- \\
0,050 \\
2,600 \\
\end{array}$ & $\begin{array}{c}1100 \\
2000 \\
2700 \\
1200 \\
- \\
0,035 \\
2500 \\
\end{array}$ & $\begin{array}{c}1700 \\
1000 \\
920 \\
840 \\
- \\
1000 \\
1000\end{array}$ \\
\hline Ceilings & & $\begin{array}{l}\text { Aluminium substructure } \\
\text { Air gap } \\
\text { Gypsum board }\end{array}$ & $\begin{array}{c}- \\
0,600 \\
0,022\end{array}$ & $\begin{array}{c}- \\
0,230 \\
0,160\end{array}$ & $\begin{array}{c}- \\
1,23 \\
950\end{array}$ & $\begin{array}{c}- \\
1006 \\
840\end{array}$ \\
\hline Roof & & $\begin{array}{l}\text { Aluminium sheet metal plates } \\
\text { Synthetic (Wolfin) foil } \\
\text { Geotextile layer } \\
\text { Wooden boards } \\
\text { Stone wool } \\
\text { Wooden beams } \\
\text { Reinforced concrete slab MB } 30\end{array}$ & $\begin{array}{l}0,001 \\
0,024 \\
0,002 \\
0,002 \\
0,100 \\
0,100 \\
0,200 \\
\end{array}$ & $\begin{array}{c}160,000 \\
0,190 \\
- \\
0,170 \\
0,035 \\
0,170 \\
2.60 \\
\end{array}$ & $\begin{array}{c}2800 \\
87 \\
0,20 \\
550 \\
30 \\
550 \\
2500 \\
\end{array}$ & $\begin{array}{c}896 \\
840 \\
- \\
2500 \\
1000 \\
2500 \\
1000 \\
\end{array}$ \\
\hline Glazing & & Clear float glass & - & 1,45 & 2500 & 910 \\
\hline
\end{tabular}

Table 1. Detailed properties of construction material used in the building

\subsection{Thermal bridges and infiltration}

For the model of business building in Tomislavgrad the list of thermal bridges is shown in Figure 3.a. Values used in the IDA ICE software have been obtained by studying cases in the literature [5], [6], [7], [8], [9]. The determination of the coefficients from the above mentioned literature was made for similar materials and compounds as in the EPHZHB business building in Tomislavgrad. These are approximate values due to the complexity of the procedure for determining the thermal bridges. We did not have the ability to do a detailed examination of the building for that purpose.

Infiltration values are taken from the research of blower-door test from the other pilot building in the project (Faculty of Electrical Engineering and Computing building - UNIZGFER skyscraper building) [10]. We took the same data for "Air tightness": $3.7 \mathrm{ACH}$ and "at pressure difference": $50 \mathrm{~Pa}$. Infiltration for business building in Tomislavgrad defined in IDA-ICE is shown in Figure 3.b.

\subsection{Heating/cooling system installations}

Heating/cooling according to the main mechanical installation project, building is provided with following installations [11]:

- Heat pump

- Engine room

- Fan coil installation

- Radiators installation

- Air handling units

- Server room cooling

- Ventilation

- Automatic regulation system 


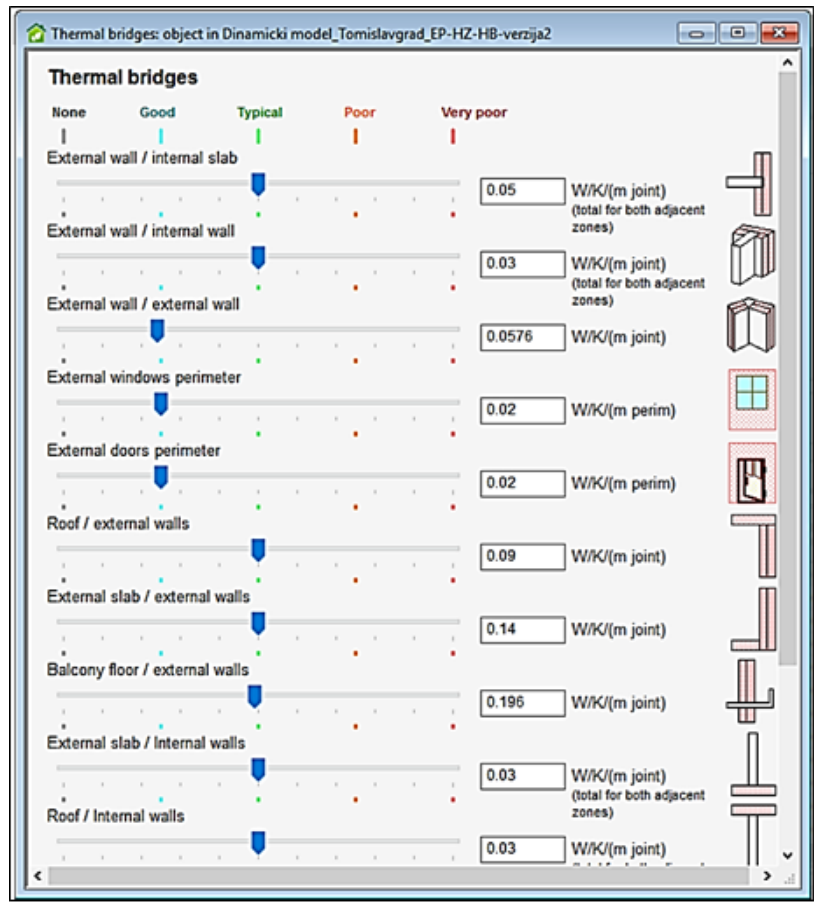

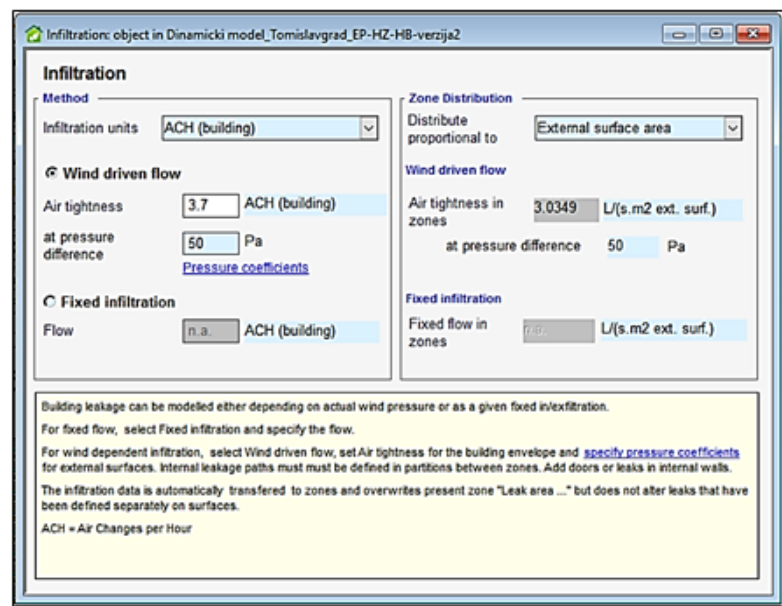

b)

Fig. 3. a) Building thermal bridges defined in IDA-ICE; b) Infiltration for building defined in IDA-ICE

To ensure cold (hot) water $7 / 12^{\circ} \mathrm{C}\left(45 / 40^{\circ} \mathrm{C}\right)$, a heat pump with air-cooled condenser is installed. Water circulation is ensured via circulation pumps. Electricity is used as a basic energy source, and an electric boiler $88 \mathrm{~kW}$ is also placed in the engine room as an additional one, and at the temperatures below $7{ }^{\circ} \mathrm{C}$ as basic hot water source. Heating and cooling of the offices, conference rooms and halls are provided by parapet and ceiling fan coils. Steel panel radiators are provided in sanitary facilities, and they are connected to the fan coil pipeline. Ventilation is done via channel fans, suction valves, grilles and air ducts. Automatic regulation system and central monitoring and control system include management and control of HVAC. [11]

\section{Building simulation model in IDA-ICE software}

Based on all the information given, detailed building model is constructed in simulation software IDA-ICE [3]. Figure 4 shows 3D model of the building with: 3D view of the whole building, sectioned 3D view of first floor and 3D model of typical zones.

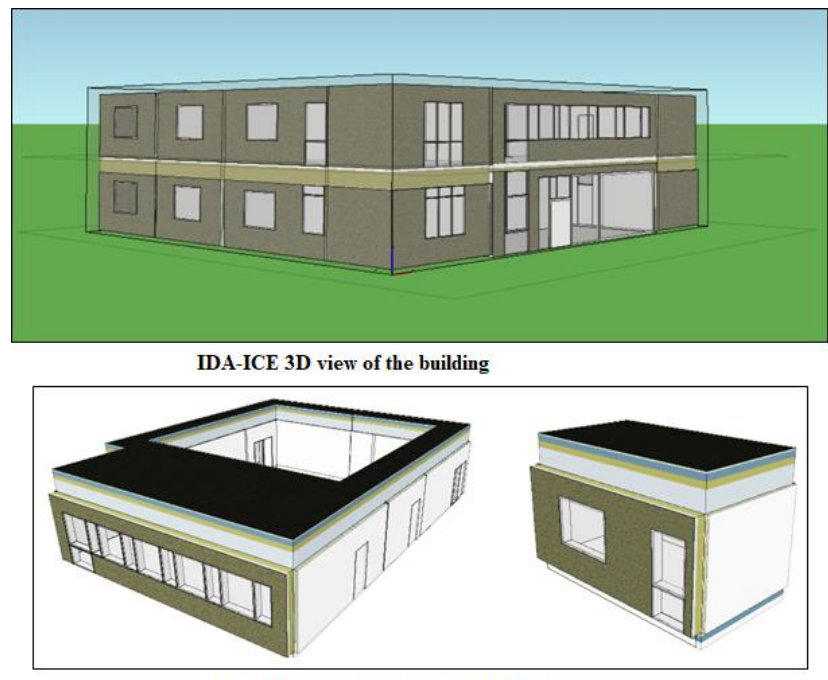

Typical zone used: hallway and office

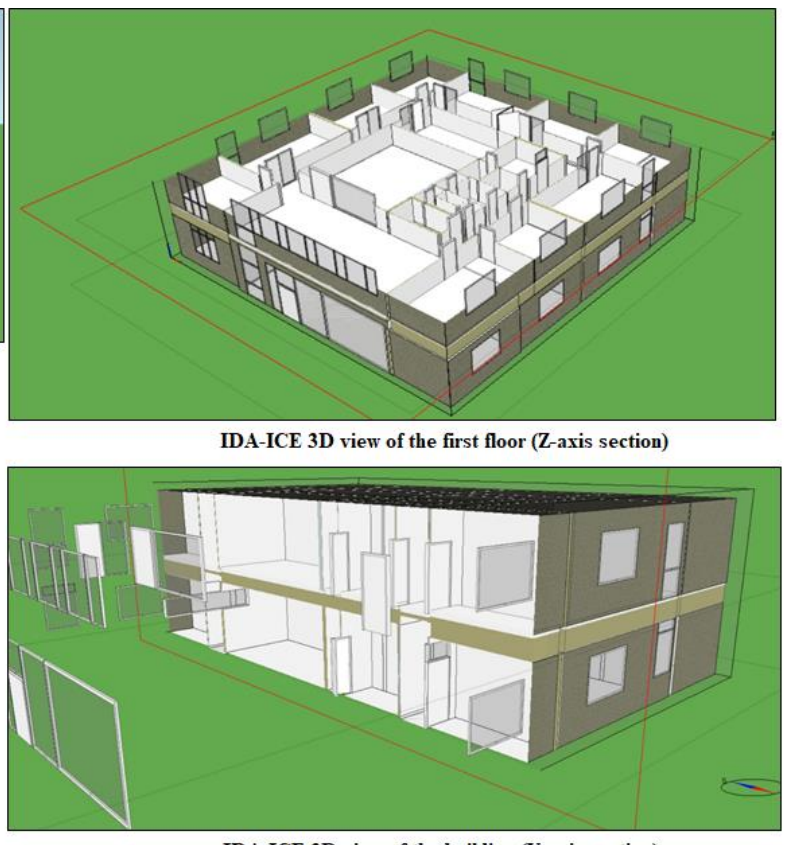

IDA-ICE 3D view of the building ( $\mathrm{Y}$-axis section)

Fig. 4. IDA-ICE 3D model of the building 


\section{Simulation scenario and responses}

Simulation scenario is chosen to fit the building occupancy profile, heating and cooling demands, window opening scenarios, etc.

Heating and cooling system in the building is a typical two-pipe system which implies seasonal heating and cooling. Cooling season covers approximately the period from May, 15th until October, 1st. The rest of the year only heating is available. On a daily basis heating/cooling system operates in two regimes, daily regime defined with working hours from 6:00-18:00 h and night regime outside working hours. During cooling season, temperature is regulated only in daily regime. In heating season, temperature is regulated in both regimes. In daily regime user can set arbitrary comfort conditions within some reasonable temperature range. Night regime is set automatically.

Occupancy schedules for the zones used as offices are generated in accordance with the zones occupancy from for EPHZHB business building technical documentation [3]. It is assumed that offices are not occupied during weekends and holidays. For all offices, it is assumed that working hours are from 08:00-17:00 h, with working break from 12:00-13:00. To simulate the occupancy of toilets, kitchenettes, hallways and stairways, cumulative occupancy is simulated such that each of these zones is occupied with 2 persons per hour. To speed up the simulations, door opening is not simulated due to the usually short duration of such interrupts.

Since building does not have air handling units installed for every room in the building, the fresh air supply depends on window opening. Air handling unit provides fresh air supply as well as ventilation for conference room on the ground floor, regulation room on first floor, hallways, restrooms and for all other rooms that do not have exterior walls. To ensure the fresh air, a ceiling air-chamber is located in lowered ceilings, for each room in particular. Air handling unit consists of:

- $\quad$ pressure fan

- $\quad$ air heater/air cooler with G3 filter

- regulatory blinds.

The air handling unit has the heater/cooler built-in regulator set, which maintains the temperature of the intake air in the winter time $22{ }^{\circ} \mathrm{C}$, and in the summer time $24{ }^{\circ} \mathrm{C}$. The heater has the freezing protection. In transition periods, the fresh air supply system can, apart from the ventilation, cover any heat loss or heat gain. For all other rooms/zones (mainly for offices) fresh air is obtained by occasionally opening the windows. Opened windows with active heating/cooling are major sources of unnecessary energy dissipation. Since window opening is inevitable for ensuring healthy working environment, in the simulation scenario windows are opened two times per 30 minutes during in one working day (from 08:00 - 17:00 h). The windows are opened from 08:00 - 08:30, and then again from 13:00 - 13:30. In all zones only one window is opened at the same time.

Lighting in the building is LED lighting so it does not contribute significantly to overall thermal energy consumption. Lighting is simulated such that the lights are on when zone is occupied and light intensity is below 500 Lux. The lights are turned off when daylight in office reaches 10000 Lux. Rated input per unit is $50 \mathrm{~W}$. Electrical equipment is allocated across the model such that every person in every permanently occupied zone, has its own personal computer and monitor, and one printer per office with $150 \mathrm{~W}$ emitted heat per unit.

Weather data used for simulations are data gathered on a meteorological station close to the business building for year 2016. The data are provided by project partner EPHZHB. The data comprises outdoor temperature, direct and diffuse solar irradiance, wind speed and direction, and humidity.

\section{Simulation results}

Monthly energy demand for the simulation scenario in IDA-ICE software, defined in Chapter 5, for heating and cooling season in 2016 is given in Table 2.

Monthly energy consumption for heating and cooling seasons in 2016. is shown on graph depicted on Figure 5. Total floor area of the building is $973,85 \mathrm{~m} 2$ so thermal energy demand for heating in simulation scenario, for 2016 ., is $\mathbf{7 7 , 4 1}$ $\mathbf{k W h} / \mathbf{m}^{2}$.

When running the simulation, one can choose an arbitrary sampling time for the zone level data such as mean air temperature, operative temperature, heat from heating and/or cooling room units, window thermal losses, heat from lighting, heat from occupants, etc. Such information can be of great importance for running a building model identification procedure when data from a real building are missing or are hard to reach. To capture the behaviour and impact of all disturbances affecting the building behaviour minute sampling time has been chosen. 


\begin{tabular}{|c|c|c|c|c|c|c|}
\hline \multirow{2}{*}{\multicolumn{3}{|c|}{ Month }} & \multicolumn{2}{|c|}{ Thermal energy consumption (zone level) [kWh] } & \multirow{2}{*}{\multicolumn{2}{|c|}{ Season }} \\
\hline & & & For heating & For cooling & & \\
\hline 1. & \multicolumn{2}{|c|}{ January } & $15.179,0$ & 3,8 & \multirow{4}{*}{\multicolumn{2}{|c|}{ Heating season }} \\
\hline 2. & \multicolumn{2}{|c|}{ February } & $10.198,0$ & 24,2 & & \\
\hline 3. & \multicolumn{2}{|c|}{ March } & $9.157,0$ & 181,3 & & \\
\hline 4. & \multicolumn{2}{|c|}{ April } & $4.452,0$ & 231,5 & & \\
\hline 5. & May & May & $2.200,0$ & $1.210,0$ & Heating & Cooling \\
\hline 6. & \multicolumn{2}{|c|}{ June } & $1.063,0$ & $1.875,0$ & \multirow{3}{*}{\multicolumn{2}{|c|}{ Cooling season }} \\
\hline 7. & \multicolumn{2}{|c|}{ July } & 811,1 & $3.052,0$ & & \\
\hline 8. & \multicolumn{2}{|c|}{ August } & 900,5 & $2.554,0$ & & \\
\hline 9. & Sept. & Sept. & $2.181,0$ & $1.085,0$ & Cooling & Heating \\
\hline 10. & \multicolumn{2}{|c|}{ October } & $5.092,0$ & 420,0 & \multirow{3}{*}{\multicolumn{2}{|c|}{ Heating season }} \\
\hline 11. & Nor & aber & $9.005,0$ & 41,3 & & \\
\hline 12. & \multicolumn{2}{|c|}{ December } & $15.143,0$ & 4,3 & & \\
\hline \multicolumn{3}{|c|}{ Overall: } & $75.381,6 \mathrm{kWh}$ & $10.682,3 \mathrm{kWh}$ & & \\
\hline
\end{tabular}

Table 2. Monthly zone level thermal energy consumption during heating and cooling season in 2016.

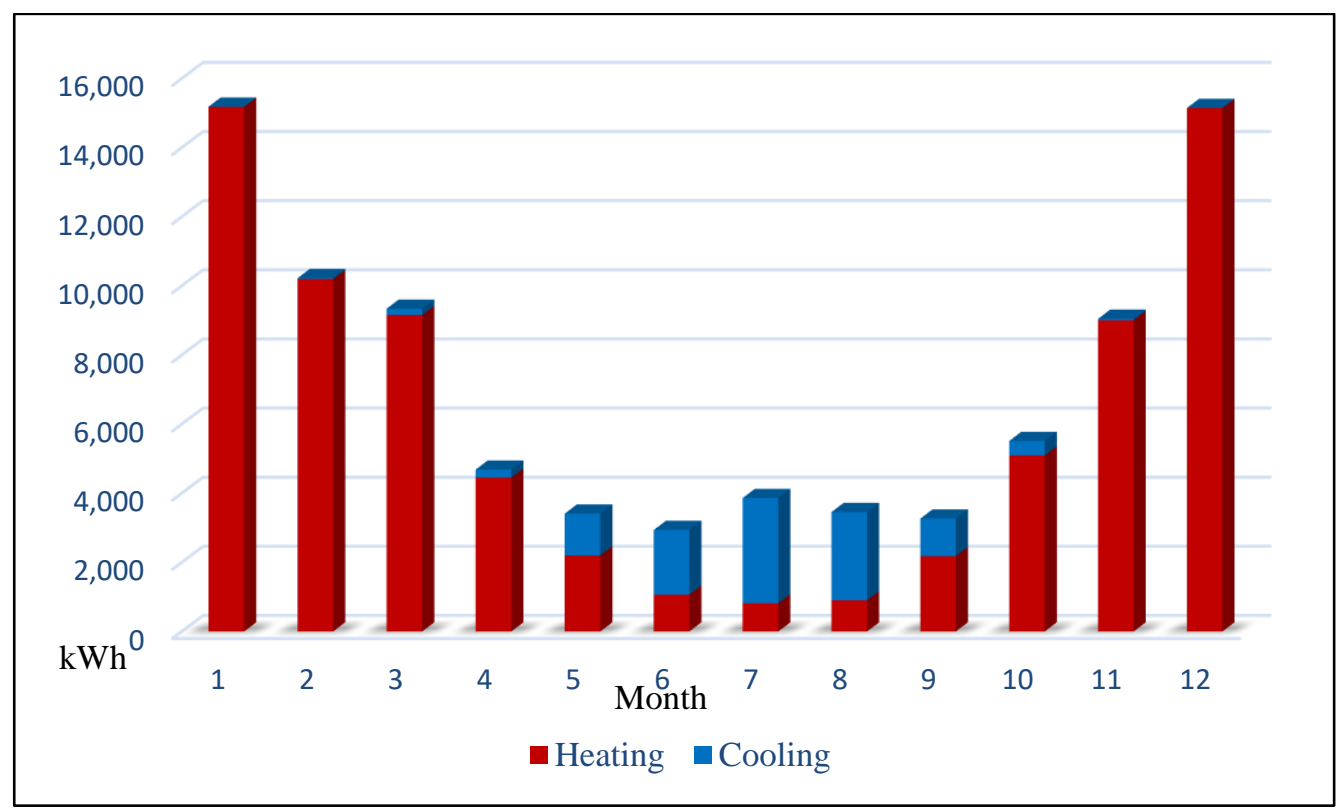

Fig. 5. Monthly energy consumption for heating/cooling in 2016 - IDA-ICE simulation

Simulation results for typical south oriented zone with the construction as shown on Figure 6.
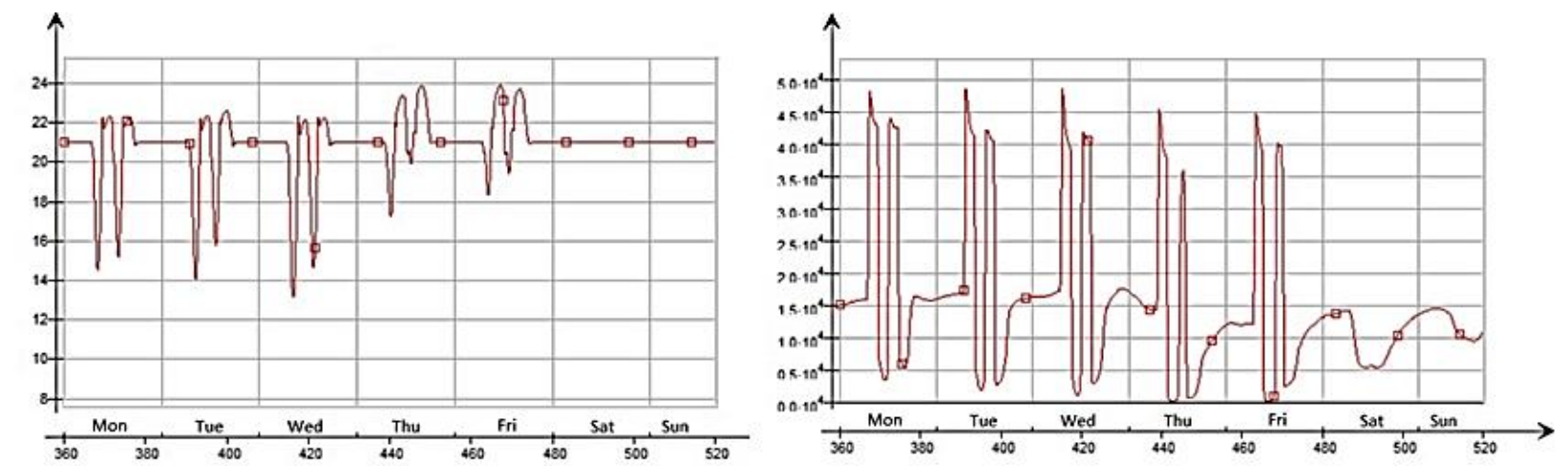

$\rightarrow-$ Mean air temperature, Deg-C

$\rightarrow-$ Ideal heaters and other local units. W

Fig. 6. Simulation results for typical south oriented office for the period from January 16. - 22.2016. 
Daily zone temperature variations for an arbitrary selected north oriented zone are shown on Figure 7.
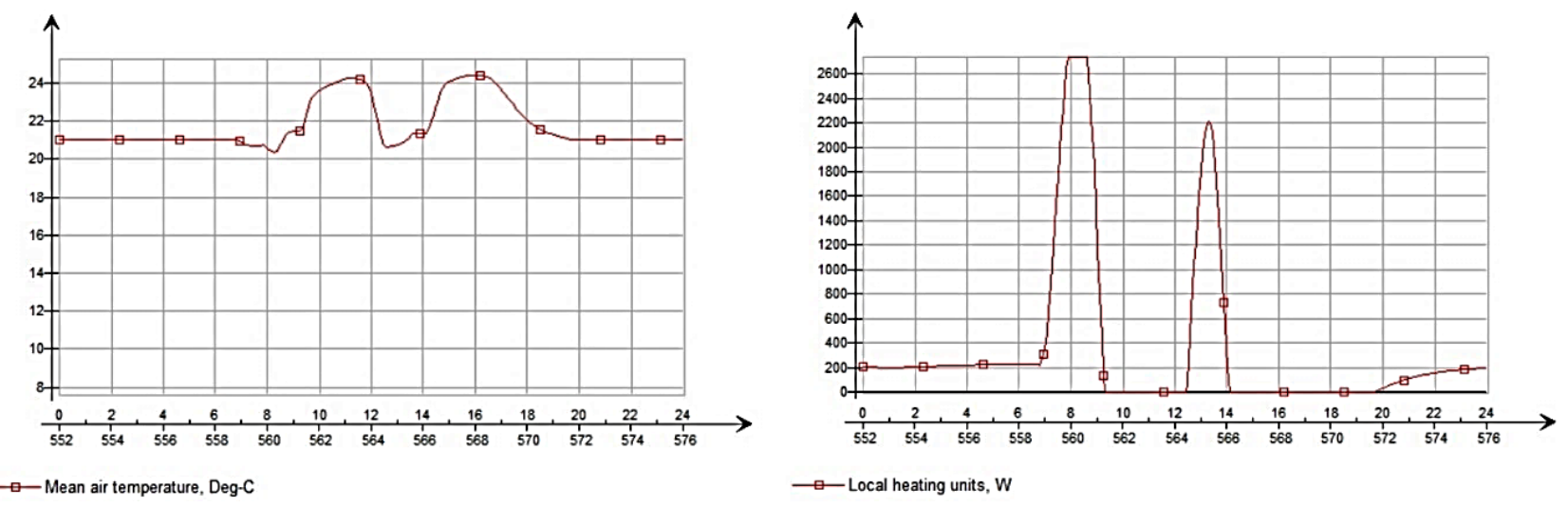

Fig. 7. Simulation results for an arbitrary selected north oriented zone on January 23. 2016.

\section{Comparison with the real data}

Total monthly energy demand for the EPHZHB business building during heating and cooling season in 2016. is given in Table 3.

\begin{tabular}{|c|c|c|c|c|c|c|}
\hline \multicolumn{3}{|c|}{ Month } & \multicolumn{2}{|c|}{$\begin{array}{l}\text { Energy consumption for entire building } \\
\qquad[\mathrm{kWh}]\end{array}$} & \multicolumn{2}{|c|}{ Season } \\
\hline 1. & \multicolumn{2}{|c|}{ January } & 17.370 & - & \multirow{4}{*}{\multicolumn{2}{|c|}{ Heating season }} \\
\hline 2. & \multicolumn{2}{|c|}{ February } & 15.028 & - & & \\
\hline 3. & \multicolumn{2}{|c|}{ March } & 17.503 & - & & \\
\hline 4. & \multicolumn{2}{|c|}{ April } & 8.517 & - & & \\
\hline 5. & May & May & \multicolumn{2}{|c|}{10.529} & Heating & Cooling \\
\hline 6. & \multicolumn{2}{|c|}{ June } & - & 2.930 & \multirow{3}{*}{\multicolumn{2}{|c|}{ Cooling season }} \\
\hline 7. & \multicolumn{2}{|c|}{ July } & - & 3.991 & & \\
\hline 8. & \multicolumn{2}{|c|}{ August } & - & 3.787 & & \\
\hline 9. & Sept. & Sept. & \multicolumn{2}{|c|}{3.505} & Cooling & Heating \\
\hline 10. & \multicolumn{2}{|c|}{ October } & 5.599 & - & \multirow{3}{*}{\multicolumn{2}{|c|}{ Heating season }} \\
\hline 11. & \multicolumn{2}{|c|}{ November } & 7.557 & - & & \\
\hline 12. & \multicolumn{2}{|c|}{ December } & 13.618 & $=$ & & \\
\hline \multicolumn{3}{|c|}{ Overall: } & $95.725 \mathrm{kWh}$ & $14.216 \mathrm{kWh}$ & & \\
\hline
\end{tabular}

Table 3. Monthly energy consumption during heating and cooling season in 2016.

Months are separated by the heating season and the cooling season. Only May and September fall in both seasons, so in that two months part of energy consumption is used for heating and part for cooling. By analysing the results of the simulation, and climate conditions in those months, we concluded that:

- In May approximately $80 \%$ of thermal energy was used for heating, and $20 \%$ of thermal energy was used for cooling.

- In September approximately $80 \%$ of thermal energy was used for cooling and $20 \%$ of thermal energy was used for heating.

Presented results are measured as the energy consumed for the entire building. These measurements are reduced by the energy consumption of lighting, computer equipment and other smaller consumers. Because we do not have precise results of separate energy consumption for heating/cooling, an estimation has been made that this group of electrical equipment has part in total energy consumption with approximately average of $1100 \mathrm{kWh} / \mathrm{month}$. Here we have to consider the essential information from EPHZHB that in 2016. only the ground floor of the building was in use. The first floor was not used (the staff did not work in the offices), however, heating and cooling systems worked throughout the year. Taking this into account, Table 4 shows approximately monthly energy demand for heating and cooling season in 2016. 


\begin{tabular}{|c|c|c|c|c|c|}
\hline \multirow{2}{*}{\multicolumn{2}{|c|}{ Month }} & \multicolumn{2}{|c|}{ Thermal energy consumption (zone level) [kWh] } & \multirow{2}{*}{\multicolumn{2}{|c|}{ Season }} \\
\hline & & For heating & For cooling & & \\
\hline 1. & January & 16.271 & - & \multirow{4}{*}{\multicolumn{2}{|c|}{ Heating season }} \\
\hline 2. & February & 13.929 & - & & \\
\hline 3. & March & 16.404 & - & & \\
\hline 4. & April & 7.417 & - & & \\
\hline 5. & Ma May & 7.543 & 1.886 & Heating & Cooling \\
\hline 6. & June & - & 1.831 & \multirow{3}{*}{\multicolumn{2}{|c|}{ Cooling season }} \\
\hline 7. & July & - & 2.892 & & \\
\hline 8. & August & - & 2.678 & & \\
\hline 9. & Sept Sept. & 481 & 1.925 & Cooling & Heating \\
\hline 10. & October & 4.500 & - & \multirow{3}{*}{\multicolumn{2}{|c|}{ Heating season }} \\
\hline 11. & November & 6.458 & - & & \\
\hline 12. & December & 12.518 & - & & \\
\hline \multicolumn{2}{|r|}{ Overall: } & $85.521 \mathrm{kWh}$ & $11.212 \mathrm{kWh}$ & & \\
\hline
\end{tabular}

Table 4. Monthly zone level approximately thermal energy consumption during heating and cooling season in 2016.

Total floor area of the building is $973,85 \mathrm{~m}^{2}$ so thermal energy demand for heating in 2016 is $\mathbf{8 7 , 8 2} \mathbf{~} \mathbf{W h} / \mathbf{m}^{\mathbf{2}}$, and for cooling is $\mathbf{1 1 , 5 1} \mathbf{~ k W h} / \mathbf{m}^{2}$. Monthly energy consumption for heating and cooling in 2016. is shown on graph depicted on

Fig. 8.

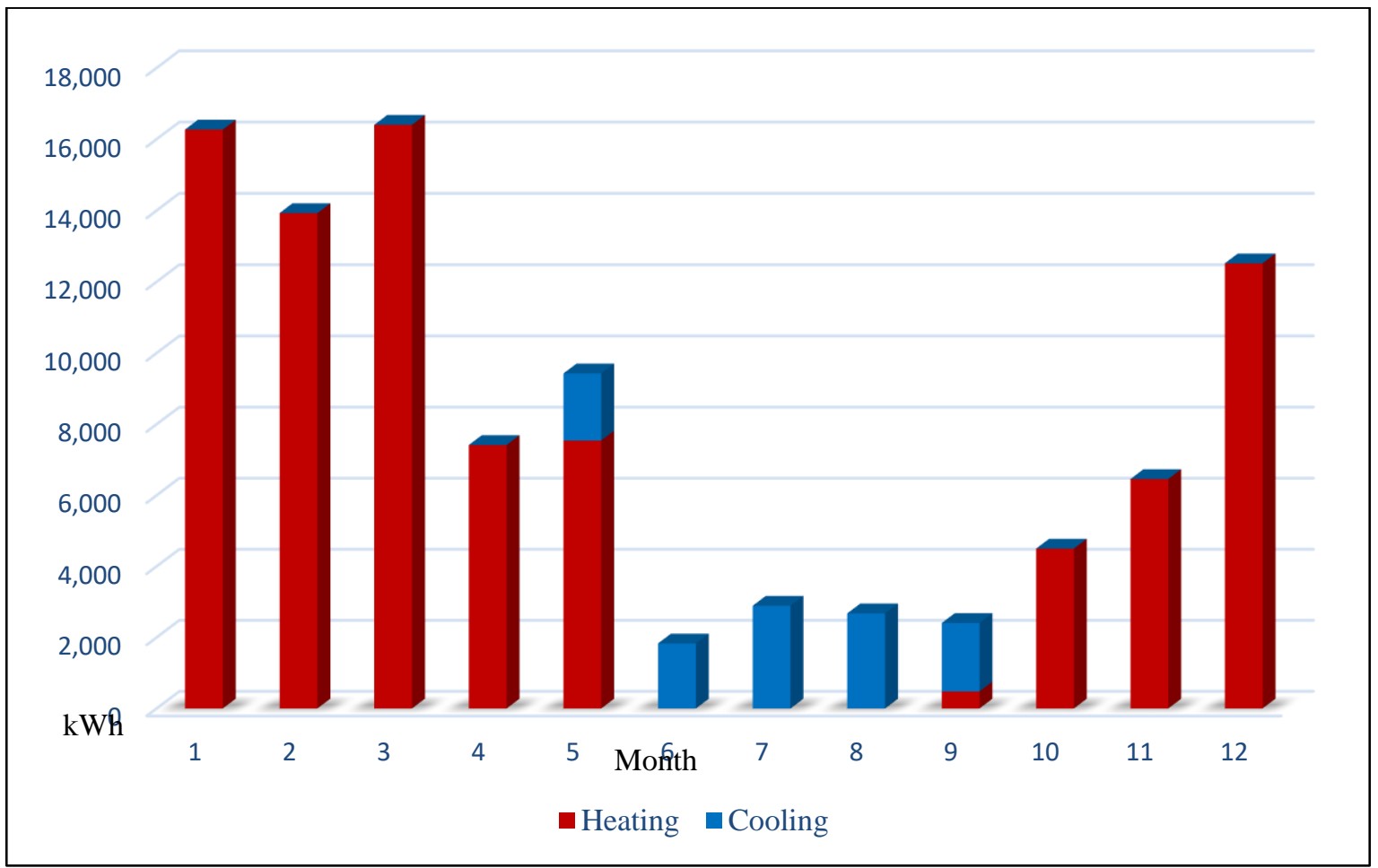

Fig. 8. Monthly energy consumption for heating and cooling in 2016.

In 2016, the total energy consumption in the building was $109.941 \mathrm{kWh}$, thereof thermal energy consumption was $96.733 \mathrm{kWh}$, which is $88 \%$ of the total energy consumption in the building. When compared with the simulation results, the real thermal energy consumption in 2016. is in average $\mathbf{1 1 \%}$ higher than the expected building consumption defined with the expected use scenarios. This implies possible energy savings over 11\%, i.e. approximately 5.000 KM (2.500 EUR) per year when the building usage would be aligned with the presumed simulation scenario.

Comparison of simulation scenario results in IDA-ICE and real energy consumption in 2016. is shown on graph depicted on Figure 9. 


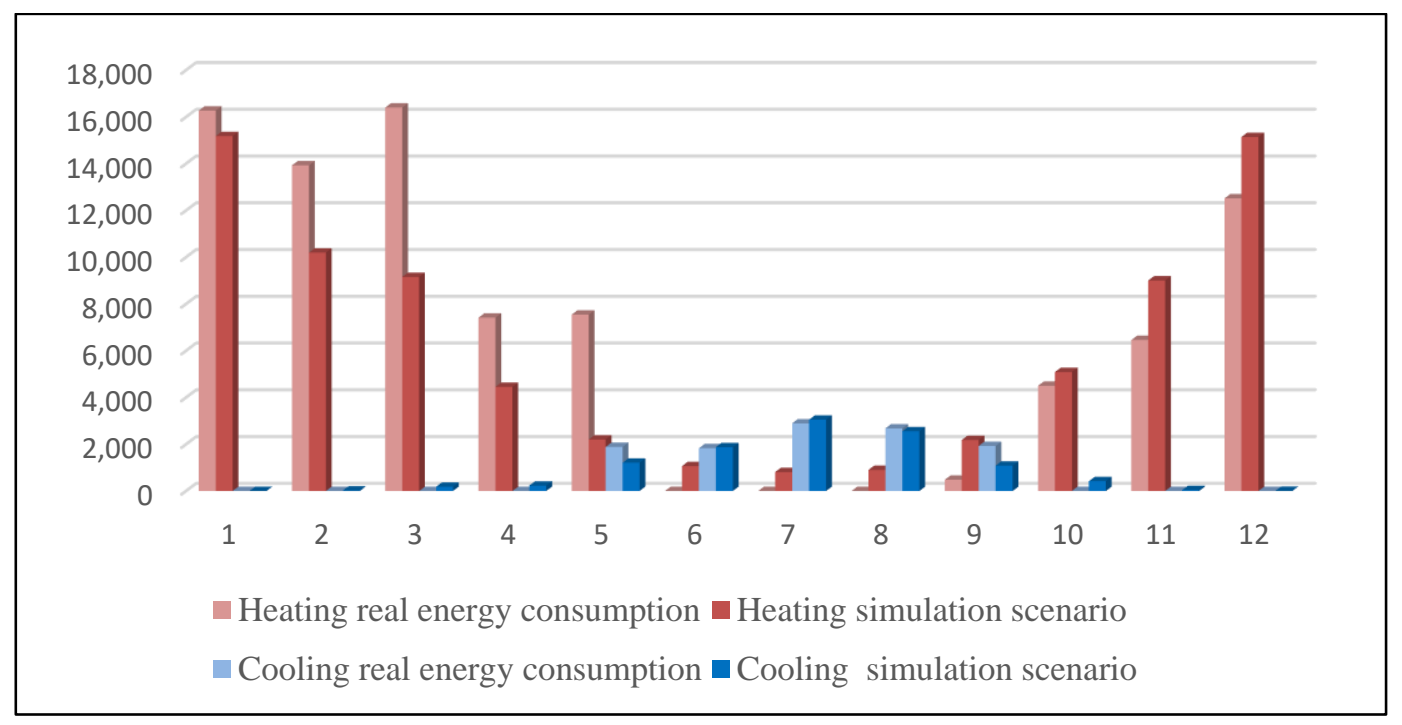

Fig. 9. Comparison of simulation scenario results in IDA-ICE and real energy consumption in 2016.

\section{Conclusion}

This paper presents a comparison of energy consumption parameters obtained from the energy dynamic model of the building and actual energy consumption parameters, as the basis for development of the future modular Model Predictive Control system. Comparison implies possible energy savings over $11 \%$, i.e. per year when the building energy usage would be aligned with the presumed simulation scenario. Energy savings obtained through simulation in IDA-ICE takes into account weather data, comfort requirements and heat disturbance estimation to optimize energy consumption in each zone (room). This concept represents the basis for development of modular MPC system for pilot buildings in 3Smart project. Most of the buildings in the Danube region has analogous problem with building-side EMS. EMS is either nonexisting or it is limited to particular ineffective subsystems. Such deficiencies result in excessive energy consumption, and ultimately with economical underperformance of a building. This knowledge provides the ability to create an optimized EMS in the building, and sets a good basis for creating modular software tool for energy management on building side. This concept will result significant economic gains and improved comfort compared to conventional EMS systems. The savings that would arise from this innovative EMS would not be negligible, especially when considering the application of such a system to larger buildings, even to entire cities.

\section{References}

[1] Birkeland J. (2002) "Design for Sustainability: A Sourcebook of Integrated, Eco-logical Solutions", Birkeland J., Eartscan Publications Ltd, 1-274, Sterling, ISBN: 1853838977,9781853838972

[2] Martinčević A., Vašak M., Lešić V. (2016) "Model predictive control for energy-saving and comfortable temperature control in buildings", IEEE, Control and Automation (MED), Athens

[3] 3SMART project documentation (2017); [Online]. Available: http://www.interreg-danube.eu/approvedprojects/3smart

[4] I.P.N. d.o.o. for design execution and supervision (2012), The main project of a business building in Tomislavgrad, Book I. Project Architecture, Posušje

[5] EQUA Simulation AB, IDA Indoor Climate and Energy, Sweden. [Online]. Available: http://www.equasolutions.co.uk/en/software/idaice

[6] Little J., Arregi B., (2011) „Thermal Bridging-Understanding its critical role in energy efficiency“, Construct Ireland, Issue 6., Vol. 5, 2011.

[7] Whale L. (2016), „An introductory guide to thermal bridging in homes“, Zero Carbon Hub, London

[8] Schöck Isokorb®, (2014) „Design Guide-Solutions to Prevent Thermal Bridging“, Kitchener, Ontario

[9] Constructive Details Ltd, (2014) „Thermal bridging solutions for external wall cavity details using Porotherm“, Bucknalls Lane, Watford

[10] Martinčević A., Vašak M., (2017) "Dynamic building model for building simulation in a professional tool UNIZGFER skyscraper building”, 3Smart Deliverable D4.5.1, [Online]. Available: http://www.interregdanube.eu/approved-projects/3smart/section/deliverables

[11] Starčić A., Vašak M., Mandrapa S., Međugorac M., et al. (2017) "Pilots conceptual projects with detailed analysis of pilot's current technical state and requirements and preliminary cost-benefit analysis of the planned investments", 3Smart Deliverable D6.2.1, [Online]. Available: http://www.interreg-danube.eu/approvedprojects $/ 3 \mathrm{smart} / \mathrm{section} /$ deliverables 